\title{
THE INFLUENCE OFFINANCIAL DISTRESS, COMPANY CHARACTERISTIC AND CORPORATE GOVERNANCE ON VOLUNTARY DISCLOSURE IN AN ANNUAL REPORT
}

\author{
Yolanda Gusvia Putri \\ Accounting, Economy, Pamulang University, Jl. Surya Kencana No. 1, South Tangerang, 15412, Indonesia \\ E-mail: dosen02543@unpam.ac.id
}

\begin{abstract}
This study aims to examine the influence of the financial distress, profitability, liquidity, firm size, commissioners and audit committee on voluntary disclosure in the annual report of manufacturing companies listed on Indonesia Stock Exchange over period of 2012 to 2016. The population of this study is manufacturing companies listed on Indonesia Stock Exchange. There are 33 manufacturing companies that fit the criteria. After filtering the companies using the purposive sampling method, there are 14 manufacturing companies used in this study. The results of the study show that: (1) financial distress does not have any significant influence on voluntary disclosure; (2) profitability does not have any significant influence on voluntary disclosure; (3) liquidity does not have any significant influence on to voluntary disclosure; (4) firm size does not have any significant influence on voluntary disclosure; (5) the audit committee does not have any significant influence on voluntary disclosure; and (6) the board of commissioners has a significant influence on voluntary disclosure.

Keywords: financial distress; corporate characteristics; commissioners; audit committee; voluntary disclosure

JEL Classification: G34, O16, M41
\end{abstract}

Article info:

Received 11 December 2020

Revised 11 December 2020

Accepted 11 December 2020

Available online 11 December 2020

\section{INTRODUCTION}

Financial statements are an essential tool for obtaining information on the financial position and achievements of a company. The primary purpose of financial statements is to provide information about the company's financial condition. This information is useful for most of the people involved in economic decision-making in a company as well as to demonstrate the stewardship or responsibility of the management in utilizing resources entrusted to it. A company reports its financial information in financial statements and annual reports. An annual report is a report on the progress and achievements of an organization over a year, published by the organization to provide its financial and non-financial information. Creating an annual report requires study about the totality of the disclosure and the influencing factors in the annual report. Study is crucial to illustrate the conditions of a company. It is also able to show the difference in the extent of disclosure of each company. Information disclosed in the annual report can be categorized into two groups: mandatory disclosure and voluntary disclosure. Mandatory disclosure is a minimum disclosure required by the applicable accounting regulations or standards. A company has to disclose its annual report transparently and thoroughly according to the applicable laws. Voluntary disclosure is a choice made by the management of a company to provide accounting or other relevant information for decision-making by the annual report users. Voluntary disclosure is crucial 
for a company in preparing its financial statements to prevent knowledge asymmetry that could cause tension between the management and shareholders. In addition, voluntary disclosure might help to minimize the cost that can manifest from the knowledge asymmetry between the management and the shareholder. With voluntary disclosure, financial statements will be more comprehensive in providing information on the commercial practices of the company. This move also will show the transparency of the company. This practice fits the agency theory, which states that there is a possibility for the management (agent) to act in its self-interest by sacrificing the other party/owner's interest. This scenario might happen because the manager has detailed information on the company that cannot be accessed by the owner of the company (principal). This situation creates information gaps.

The first factor that will become the variable of this study is financial distress, a condition that a company goes through before it experiences bankruptcy. A company might have good news and bad news, such as financial distress. A company with financial distress tends to disclose less information than a healthy company. It makes more sense that companies will try to hide disadvantageous info from the public (Nasir and Abdullah, 2004). The second factor is the profitability ratio, one of the aspects of measuring the performance of a company. Companies with high profitability will disclose their financial statements more openly. The higher the profitability ratio of a company, the higher the ability to generate profit and the better the performance of the company will be. When a company makes big profits, it will have enough funds to gather, group, and manage its information to become more useful and to disclose information more comprehensively. Therefore, a company with high profitability will be more courageous in disclosing its report. The third factor is the liquidity rate. Liquidity is a ratio that measures the performance of a company in meeting its short-term obligations to the short-term creditor (Hanafi and Halim, 2005). The capability of the company, shown by its high liquidity ratio, is related to the greater extent of or more comprehensive disclosure of financial statements. The fourth factor is firm size, a factor that influences the extent of disclosure of a company. The bigger the size of a company, the greater the extent of the disclosure because big companies have to meet public demand to disclose more information (Halim et al., 2005). This instance indicates that big companies tend to disclose more information than small companies. Small companies are usually in a more competitive position with other companies. Therefore, for small companies, revealing too much information to external parties could endanger their place in the competition. A company is in a good condition if it uses corporate governance. Voluntary disclosure is related to corporate governance, which is the proportion of the Board of Commissioners and the Audit Committee because applying corporate governance will create transparency and accountability in the company. Companies that implement corporate governance will provide more information to decrease information asymmetry.

\section{LITERATURE REVIEW}

\subsection{Agency theory}

Agency theory is a relationship between one or more principals to ask another agent to perform a task related to the interest of the principal (Jensen and Meckling, 1976). The principal is the shareholder of a company, and the agent is the management of the company. The principal provides facilities and funds for running the company, while the management has an obligation to manage what the stakeholders told them to. The agent is required to provide a periodical report to the principal regarding the business it runs. The principal will evaluate the performance of the agent through the provided financial statements. Therefore, financial statements are suggestions on management accountability to the owner. A greater extent of the disclosure will decrease the cost of the agency paid by the company. The greater 
the information disclosed by the management (agent), the lesser the conflict among the shareholder (principal), which will prevent information asymmetry.

\subsection{The basic concepts}

Voluntary disclosure is a disclosure performed voluntarily by a company without being mandated by the authorized agency. A voluntary disclosure will be different in each company. This variety occurs because there is no regulation on the extent of voluntary disclosure, so any company is free to pick the type of information to disclose and perceive as relevant in helping the decision-making process. Voluntary disclosure is openness in disclosing material and information about the company (Tunggal, 2014:41).

Financial distress is a financial problem faced by a company, starting with its inability to fulfill its obligations, especially short-term obligations, including liquidity obligations and obligations in the solvability category. Financial distress is a situation where the cash flow of a company is not sufficient enough to pay its current liabilities (such as accounts payable and interest expense), and the company has to perform several improvements (Hapsari, 2012).

The profitability ratio is a ratio to rate the ability of a company to make a profit (Kasmir, 2012:196). Ratio profitability also referred as rent ability which illustrates the ability of the company to make a profit through all abilities and available resources such as sales, cash, capital, number of employees, number of branches, etc. The ratio that illustrates the ability of a company to make a profit is also called the operating ratio (Harahap, 2007:304).

Liquidity ratio refers to the ability of a company to fulfill its short-term obligations (Subramanyam and Wild, 2011:241). The liquidity companies can use to measure their capability in fulfilling their liabilities is the current ratio (Kasmir, 2012:135).

Firm size is definable in the form of total assets, sales, and market capitalization. The bigger the total assets, sales, and market capitalization then higher the capital used by companies. Moreover, higher the sales then give higher money circulation. Also, higher the market capitalization then gives higher the popularity of a company.

The board of commissioners consists of commissioners who come from outside of a company. They are chosen independently with transparency, have sufficient integrity and competency, free from influences related to personal interest or interest of other parties, and can act objectively and independently by following the principles of good corporate governance. They have collective tasks and responsibilities to monitor and give suggestions to the directors in implementing the system of good corporate governance at organizational levels in a company.

The audit committee is a supplementary organ needed to implement good corporate governance. The board of commissioners creates this committee to help them perform examination or study required by the directors in managing the company as well as ensuring that the operation that the company runs complies with its policies. The tasks and responsibilities of an audit committee will also determine the performance and success of a company.

\subsection{Hypothesis development}

Voluntary disclosure is a disclosure carried out voluntarily and not mandated by the authorized agency. Voluntary disclosure is different in every company. This variety occurs because there is no regulation on the extent of voluntary disclosure. A company is free to pick the type of information to disclose and perceive as relevant in helping the company in the decision-making process.

The relationship of financial distress and voluntary disclosure in the annual report. A company in better financial position tends to disclose more information than a company in financial distress. Immanuel (2015) shows that financial distress has a significant influence 
on the extent of voluntary disclosure as companies with high financial distress will have voluntary disclosure less frequently. Poluan and Nugroho (2015) find that financial distress influences the extent of voluntary disclosure in the annual report of a company. Meanwhile, Dharma and Nugroho (2013) show that financial distress does not influence voluntary disclosure in an annual report.

H1: Financial distress influences voluntary disclosure in the annual report of a company.

The relationship of profitability and voluntary disclosure in an annual report. Companies with high profitability tend to disclose more information because they have more power to get information than companies with low profitability. Wiguna (2012) finds that profitability has a positive influence on the extent of voluntary disclosure in an annual report of a company. Meanwhile, Asih (2010) finds that profitability does not influence voluntary disclosure in an annual report.

H2: Profitability influences voluntary disclosure in the annual report of a company.

The relationship of liquidity and voluntary disclosure in an annual report. Companies in a stronger financial position tend to disclose financial statements more comprehensively than companies in a weaker financial position. Daniel (2013) states that liquidity has a significant and positive influence on the extent of disclosure in a report. Meanwhile, Asih (2010) shows that liquidity has a negative correlation with voluntary disclosure. Wijayanti (2013) and Anisa (2011) also show that liquidity does not influence voluntary disclosure in an annual report.

H3: Liquidity influences voluntary disclosure in the annual report of a company.

The relation between firm size and voluntary disclosure in an annual report. Stakeholders will expect big companies to withstand financial problems. Big-sized companies tend to have higher public demand for information than small-sized companies. Daniel (2013) finds that firm size has a significant and positive influence on the level of voluntary disclosure. Meanwhile, Wiguna (2012) finds that firm size does not influence voluntary disclosure in an annual report.

H4: Firm size influences the voluntary disclosure in the annual report of a company.

The relationship of the board of commissioners and voluntary disclosure in an annual report. The purpose of the board of commissioners in a company is to balance decisionmaking, especially in giving protection to the stakeholders and related parties. Poluan and Nugroho (2015) find that the size of the board of commissioners has a positive and significant influence on voluntary disclosure in an annual report. Meanwhile, Suta and Laksito (2012) find that the board of commissioners does not have a significant impact on the level of voluntary disclosure.

H5: The board of commissioners influences voluntary disclosure in the annual report of a company.

The relationship of the audit committee and voluntary disclosure in an annual report. An effective audit committee can increase internal control. It has the power to increase the extent to which a company discloses its value and increase voluntary disclosure. Immanuel (2015) shows that the audit committee has a positive and significant influence on voluntary disclosure in the annual report of a company. However, Poluan and Nugroho (2015) show that the audit committee does not influence voluntary disclosure in an annual report.

H6: The audit committee influences voluntary disclosure in an annual report of a company.

\section{RESEARCH METHOD}

\subsection{Data type and source}

This paper conducts quantitative study with an associational approach. According to Sugiyono (2010), quantitative study is a method used over specific population or sample. It collects data with instruments and analyzes quantitative or statistical data to test the 
predetermined hypothesis. Qualitative associational data analysis is a data analysis based on numbers. This study aims to find the correlation between each variable with the statistical analysis technique.

\subsection{Sample and sampling technique}

The population of this study is manufacturing companies listed on the Indonesian Stock Exchange (IDX) in the consumer goods industry sector. There are 33 companies listed on IDX from 2012 to 2016. This study uses the purposive sampling technique. The sample criteria used to choose the sample in this study are: (a) the company is a manufacturing company in the consumer goods industry sector and was listed on IDX from 2012 to 2016; (b) the company had released and published financial statements for the fiscal year that ends between 31 December 2012 and 31 December 2016; (c) the company has halal certification from the Indonesian Cleric Council; and (d) the company discloses the number of members of its board of commissioners and the frequency of its audit committee meeting. Based on the criteria above, there are 14 companies used as samples.

\subsection{Operational variable definition}

This study uses voluntary disclosure as its dependent variable, and financial distress, profitability, liquidity, firm size, the board of commissioner, and the audit committee as its independent variables. Table 1 shows the measurement of the dependent variable and the independent variables of this study.

Table 1. Operational variable definition

\begin{tabular}{|c|c|}
\hline Variable Name & Formula \\
\hline Financial distress & ICR $=$ Operating Profit $\div$ Interest Expense \\
\hline Profitability & ROA = Earnings after-tax $\div$ Total Asset \\
\hline Liquidity & $\mathrm{CR}=$ Current assets $\div$ Current liabilities \\
\hline Firm size & Size $=$ Log Natural $($ Total Asset $)$ \\
\hline $\begin{array}{l}\text { The Board of } \\
\text { Commissioners }\end{array}$ & $\begin{array}{l}\text { The number of members of the board of commissioners in the } \\
\text { company }\end{array}$ \\
\hline Audit committee & The number of meetings of the members in the audit committee \\
\hline Voluntary disclosure & $\begin{array}{l}\text { IPSt }=\sum X \text { it } \div \mathrm{N} \text {, whereIPSt is voluntary disclosure index in the } \\
\text { company } t, \sum X \text { it is the number of items disclosed by the } \\
\text { company, and } \mathrm{N} \text { the total items in the voluntary disclosure. }\end{array}$ \\
\hline
\end{tabular}

\subsection{Analysis method}

Descriptive statistics. Descriptive statistics are usually used in data analysis by describing or illustrating the collected data without drawing a generalized conclusion.

Classical assumption test. This study does several classical assumption tests so the regression test can meet the criteria of the Best Linear Unbiased Estimator (BLUE):

1. Normality test. This study conducts the normality test with the Jarque-Bera test. To make a decision, focus on Jarque-Bera and probability.

2. Multicollinearity test. This study uses a statistical test tool to test if there is a relation among independent variables. The cut-off value used to show the multicollinearity is the tolerance value of $\leq 0.10$ or equal to the Variance Inflation Factor (VIF) value of $\geq 10$.

3. Heteroscedasticity test. This study uses a white-test by regressing squared residuals as the dependent variable. The test adds the dependent variable to the squared independent variables, then adds it to the multiplication of two independent variables, the probability value of chi-square.

Multiple linear regression test. The hypothesis test in this study uses multiple linear regression analysis with a significance level of 0.05 . The regression model with panel data can be conducted with three approaches: 
1. Common effect model. It is the simplest panel data model approach because it only combines time series and cross-section data. This model does not count time or individual dimension, so the model assumes that the behavior of the company data is the same in several periods.

2. Fixed effect model. This model assumes that the differences between individuals are accommodable from the differences in its intercepts. To estimate panel data, the fixedeffect model uses the dummy variable technique to catch the intercept differences between the companies. The intercept differences might occur due to the differences in work culture, management, and incentive.

3. Random effect model. This model will estimate panel data, where the error term might correlate between times and individuals. This model accommodates intercept differences with the error terms of each company.

\section{RESULTS AND DISCUSSION}

\subsection{The results}

Descriptive statistics. Table 2 shows that profitability, liquidity, firm size, and the board of directors have a higher mean than deviation standard, which means that the data of those variables are decent and varied. Meanwhile, voluntary disclosure, financial distress, and the audit committee have a smaller mean than the deviation standard, which means that these three variables are identical and not varied.

Table 2. Descriptive statistics

\begin{tabular}{lccccccc}
\hline Variable & FINDISTR & ROA & CR & SIZE & COM & KA & VOLDISCL \\
\hline Mean & 28.79616 & 0.068491 & 2.514819 & 28.42301 & 4.114286 & 7.414286 & 0.604762 \\
Median & 4.732237 & 0.050217 & 2.010694 & 27.61952 & 3.000000 & 4.000000 & 0.575758 \\
Maximum & 458.1508 & 0.253241 & 7.904009 & 34.24297 & 8.000000 & 46.00000 & 0.878788 \\
Minimum & -2.853814 & -0.097143 & 1.059805 & 24.16949 & 2.000000 & 2.000000 & 0.363636 \\
Std. Dev. & 69.53855 & 0.076355 & 1.419054 & 2.465139 & 1.869223 & 8.247077 & 0.117469 \\
Skewness & 4.450532 & 0.474792 & 1.332891 & 0.856013 & 0.972788 & 2.960324 & 0.464170 \\
Kurtosis & 25.13424 & 2.858538 & 4.739818 & 2.975950 & 2.413686 & 12.21790 & 2.608773 \\
Jarque-Bera & 1660.032 & 2.688355 & 29.55564 & 8.550527 & 12.04300 & 350.0693 & 2.960049 \\
Probability & 0.000000 & 0.260754 & 0.000000 & 0.013908 & 0.002426 & 0.000000 & 0.227632 \\
Sum & 2015.731 & 4.794400 & 176.0373 & 1989.611 & 288.0000 & 519.0000 & 42.33333 \\
Sum Sq. & 333657.1 & 0.402279 & 138.9463 & 419.3067 & 241.0857 & 4692.986 & 0.952132 \\
Observation & 70 & 70 & 70 & 70 & 70 & 70 & 70 \\
\hline
\end{tabular}

Classic assumption test. Figure 1 shows that the Jarque-Bera value is 3,847484 with a probability value of 0,146059 . The probability value is higher than 0,05 , which means that the residuals are distributed normally.

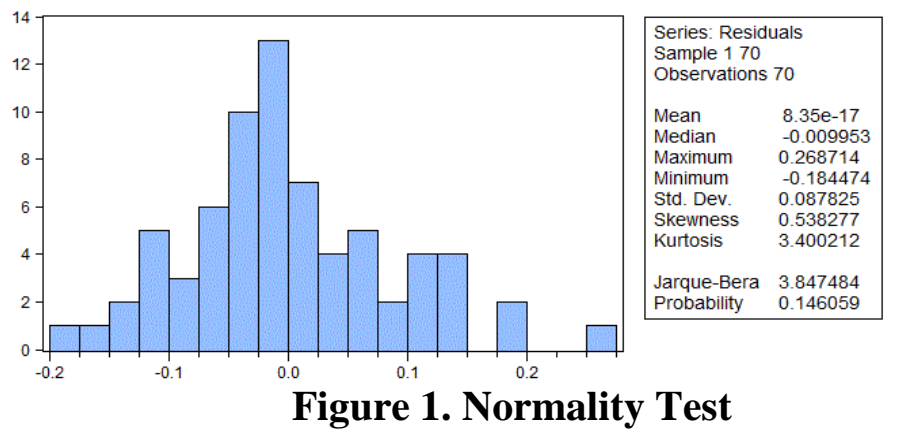

Table 3 shows that the Variance Inflation Factors (VIF) value between variables is smaller than 10. This value meets the test criteria. In the results of the multicollinearity test, there is 
no correlation coefficient value higher than ten between variables in the Centered VIF column. Therefore, the conclusion is the independent variables do not have any multicollinearity issue.

Table 3. Multicollinearity test

\begin{tabular}{lccc}
\multicolumn{1}{c}{ Variable } & Coefficient Variance & Uncentered VIF & Centered VIF \\
\hline C & 0.033087 & 274.1693 & NA \\
FINDISTR & $3.20 \mathrm{E}-08$ & 1.484449 & 1.264472 \\
ROA & 0.053646 & 4.639926 & 2.554621 \\
CR & $7.47 \mathrm{E}-05$ & 5.141312 & 1.228176 \\
SIZE & $5.26 \mathrm{E}-05$ & 354.5440 & 2.609488 \\
COM & $5.22 \mathrm{E}-05$ & 8.806082 & 1.488794 \\
KA & $2.13 \mathrm{E}-06$ & 2.151386 & 1.182112 \\
\hline
\end{tabular}

Table 4 shows that the probability value of chi-square is 0,1364 . This value is higher than the significance value of $0,05(0,1364>0,05)$. Therefore, the conclusion is the variables do not have any heteroscedasticity problem because it exceeds the predetermined significance level..

Table 4. Heteroscedasticity test

\begin{tabular}{llll}
\hline F-statistic & 1.564287 & Prob. F(27,42) & 0.0944 \\
Obs*R-squared & 35.09796 & Prob. Chi-Square(27) & 0.1364 \\
Scaled explained SS & 34.11823 & Prob. Chi-Square(27) & 0.1626 \\
\hline
\end{tabular}

Multiple linear regression test. Table 5 shows the results of the multiple regression analysis using data from the best goodness of fit model. The correct regression chosen in this study is the fixed effect model. The analysis results show the regression equation as follows.

\section{$Y=0.247430-0,000219 F I N D I S T R-0,352223 R O A+0,021914 C R+0,017902 S I Z E-0,042375 C O M-0,000249 K A$}

The probability value of financial distress (FINDISTR) on voluntary disclosure is 0,1846 $(>0,05)$, which means that financial distress does not influence voluntary disclosure. The probability value of the profitability variable (ROA) on voluntary disclosure is 0,0899 $(0>0,05)$, which means that profitability does not influence voluntary disclosure. The probability value of liquidity $(\mathrm{CR})$ on voluntary disclosure is $0,1496(>0,05)$, which means that liquidity does not influence voluntary disclosure. The probability value of firm size (SIZE) on voluntary disclosure is $0,2846(>0,05)$, which means that firm size does not influence voluntary disclosure. The probability value of the board of commissioners (COM) on voluntary disclosure is $0.0014(>0,05)$, which means that the board of commissioners does not influence voluntary disclosure. The probability value of the audit committee (KA) on voluntary disclosure is $0.08870(>0,05)$, which means that the audit committee does not influence voluntary disclosure.

Table 5. Multiple regression analysis with fixed effect model

\begin{tabular}{|c|c|c|}
\hline Variable & Coefficient & Prob. \\
\hline $\mathrm{C}$ & 0.247430 & 0.6068 \\
\hline FINDISTR & -0.000219 & 0.1846 \\
\hline ROA & -0.352223 & 0.0899 \\
\hline CR & 0.021914 & 0.1496 \\
\hline SIZE & 0.017902 & 0.2846 \\
\hline $\mathrm{COM}$ & -0.042375 & 0.0014 \\
\hline KA & -0.000249 & 0.8870 \\
\hline
\end{tabular}




\subsection{Discussion}

The relationship of financial distress and voluntary disclosure in the annual report of a company. The result of the analysis shows that financial distress does not influence voluntary disclosure in the annual report of a company; $\mathrm{H} 1$ is therefore rejected. This rejection indicates that in an unhealthy financial condition, a company will still voluntarily disclose the annual report. This study proves that some manufacturing companies listed in the observed period and underwent loss will publish financial statements outside of the mandatory disclosure. The result of this study is not consistent with the findings of Poluan and Nugroho (2015), which show that financial distress has a significant influence on the voluntary disclosure in the annual report of a company, which in effect will make a company in financial distress to disclose lesser information. This study is also not consistent with the findings of Immanuel (2015), which shows that financial distress has a significant influence on voluntary disclosure. Meanwhile, this study is consistent with the findings of Dharma and Nugroho (2013), which show that financial distress does not influence voluntary disclosure in the annual report of a company.

The relationship of profitability and voluntary disclosure in the annual report of a company. The result of the analysis shows that profitability does not influence voluntary disclosure in the annual report of a company, $\mathrm{H} 2$ is therefore rejected. This rejection indicates that high profitability is already a source of information for investors, so a company does not have to do voluntary disclosure to attract investors. The result of this study is affirmed by Asih (2010) who finds that the profitability does not influence voluntary disclosure in the annual report of a company. High probability does not translate to deeper disclosure because companies assume that stakeholders only need profitability information for their decision making.

The relationship of liquidity and voluntary disclosure in the annual report of a company. The results of the analysis show that liquidity does not influence voluntary disclosure in the annual report of a company, $\mathrm{H} 3$ is therefore rejected. This result shows that the capability of a company to fulfill its short-term liabilities does not influence the company to choose whether to disclose its report voluntarily or not. The result of this study supports the findings of Asih (2010) which show that liquidity has a negative influence on voluntary disclosure. Companies predict that with a high liquidity level, they do not need to provide more information to the stakeholders because they can fulfill all of their short-term liabilities. Wijayanty (2013) and Anisa (2011) also affirm the results of this study; liquidity does not influence voluntary disclosure in the annual report of a company.

The relationship of firm size and voluntary disclosure in the annual report of a company. The result of the analysis shows that firm size does not influence voluntary disclosure in the annual report of a company; $\mathrm{H} 4$ is therefore rejected. This result shows that the bigger the size of a company, the higher the need for better monitoring. One of the ways to meet the public demand to monitor a company is through the annual report disclosed by the company. The result of this study do not correspond with Daniel (2013), who finds that firm size has a significant and positive influence on the extent of voluntary disclosure in the annual report of a company. The bigger the firm then more comprehensive the information disclosed by it. However, the result of this study correspond with the findings of Wiguna (2012) which finds that firm size does not influence voluntary disclosure in the annual report of a company.

The relationship of the board of commissioners and voluntary disclosure in the annual report of a company. The result of the analysis show that the board of commissioners influences voluntary disclosure in the annual report of a company; H5 is therefore accepted. The big-sized board of commissioners indeed will improve the monitoring of the management, decrease agency problems, and increase transparency in the disclosure. The 
result of this study corresponds with the findings of Poluan and Nugroho (2015) which show that the Board of Commissioners influences voluntary disclosure in the annual report of a company. Therefore, a large board of commissioners can increase voluntary disclosure. However, the result of this study does not correspond with the findings of Suta and Laksito (2012) which shows that the board of commissioners does not have any significant impact on the extent of voluntary disclosure.

The relationship of the audit committee and voluntary disclosure in the annual report of a company. The result of the analysis show that the audit committee does not influence voluntary disclosure in the annual report of a company; H6 is therefore rejected. Even though companies have their audit committee, if the committee does have the financial ability, there is a large possibility that they also won't be able to face the complexity of financial reporting. This incompetency causes the audit committee to be not effective in monitoring. Consistently, Poluan and Nugroho (2015) show the same results by showing that the audit committee does not influence voluntary disclosure. The result of this study is also not consistent with the findings of Immanuel (2015), which shows that the audit committee influences voluntary disclosure.

\section{CONCLUSION}

\subsection{Conclusion}

The conclusion that can be drawn from the test results in this study is that financial distress, profitability, liquidity, firm size, and audit committee do not influence voluntary disclosure in the annual report of a company. Meanwhile, the board of commissioners influences voluntary disclosure in the annual report of a company. From an agency theory viewpoint, the results imply that the increase in the number of members of the board of commissioners tends to influence voluntary disclosure from a company.

\subsection{Suggestion}

This study suggests for further studies to use different types of companies as a comparison to the consumer-goods manufacturing companies listed on the Indonesian Stock Exchange. Other studies also need to add other corporate governance variables such as institutional ownership, managerial ownership, the board of directors, and the company secretary. Further studies also need to use more current items of voluntary disclosure applied to companies in Indonesia.

\section{REFERENCES}

Anisa, W. D. (2011). Pengaruh likuiditas, profitabilitas, ukuran perusahaan, dan kepemilikan saham publik terhadap pengungkapan laporan tahunan. Doctoral dissertation. Universitas Negeri Semarang. http://lib.unnes.ac.id/6833/1/7896.pdf

Asih, S. (2010). Faktor-faktor yang mempengaruhi tingkat pengungkapan sukarela dalam laporan tahunan dan pengaruhnya terhadap penilaian value relevance (Studi empiris perusahaan non keuangan di BEI tahun 2007-2008). Thesis. Universitas Indonesia.

https://adoc.pub/universitasindonesia483ddae689d620c33ef6d2236a4dd14c83540.html

Daniel, N. U. (2013). Pengaruh ukuran perusahaan, leverage dan likuiditas terhadap luas pengungkapan laporan keuangan. Jurnal Akuntansi Universitas Negeri Padang, 1(1), 1-24. http://ejournal.unp.ac.id/students/index.php/akt/article/viewFile/65/53

Dharma, C. Y. S., \& Nugroho, P. I. (2013). Corporate governance, financial distress, and voluntary disclosure. In Proceedings of the International Conference on 
Managing the Asian Century, 4(1), 217-224. http://doi.org/10.1007/978-9814560-61-0_25

Halim, J., Meiden, C., \& Tobing, R. L. (2005). Pengaruh manajemen laba pada tingkat pengungkapan laporan keuangan pada perusahaan manufaktur yang termasuk dalam indeks LQ-45. SNA VIII Solo, 8, 117-135. https://www.academia.edu/6785292

Hanafi, M. M., \& Halim, A. (2005). Analisis laporan keuangan, edisi kedua. Yogyakarta: AMP YKPN.

Hapsari, E. I. (2012). Kekuatan rasio keuangan dalam memprediksi kondisi financial distress perusahaan manufaktur di BEI. JDM (Jurnal Dinamika Manajemen), 3(2), 101109. https://doi.org/10.15294/jdm.v3i2.2438

Harahap, S. S. (2007). Analisis kritis atas laporan keuangan, edisi pertama, cetakan ketiga. Jakarta: PT. Raja Grafindo Persada.

Immanuel, R. Y. (2015). Pengaruh financial distress dan struktur corporate governance terhadap luas pengungkapan informasi sukarela. Diponegoro Journal of Accounting, $\quad 4(3), \quad 289-300$. https://ejournal3.undip.ac.id/index.php/accounting/article/view/16819

Jensen, M. C., \& Meckling, W. H. (1976). Theory of the firm: Managerial behavior, agency cost and ownership structure. Journal of Financial Economics, 3(4), 305-360. https://doi.org/10.1016/0304-405X(76)90026-X

Kasmir. (2012). Analisis laporan keuangan. Jakarta: PT. Raja Grafindo Persada.

Nasir, N. M., \& Abdullah, S. N. (2004). Voluntary disclosure and corporate governance among financially distressed firms in Malaysia. Financial Reporting, Regulation and Governance, $\quad 3(1), 39$. www.business.curtin.edu.au/index.cfm?objectld=55489367-D582-2975B8105F3A1FB1979

Poluan, G., \& Nugroho, P. I. (2015). Pengaruh mekanisme corporate governance dan kondisi financial distress terhadap luas pengungkapan sukarela dalam laporan tahunan perusahaan. Dinamika Akuntansi Keuangan dan Perbankan, 4(1), 39-56. https://www.unisbank.ac.id/ojs/index.php/fe9/article/view/3826

Subramanyam, K. R., \& Wild, J. (2011). Analisis laporan keuangan, edisi 10. Jakarta: Salemba Empat.

Sugiyono. (2010). Metode penelitian kuantitatif, kualitatif dan R\&D. Bandung: CV. Alfabeta.

Suta, A. Y., \& Laksito, H. (2012). Analisis faktor-faktor yang mempengaruhi luas pengungkapan informasi sukarela laporan tahunan (Studi empiris pada perusahaan manufaktur yang terdaftar di Bursa Efek Indonesia tahun 2008-2010). Doctoral dissertation. Universitas Diponegoro. http://eprints.undip.ac.id/35989/1/SUTA.pdf

Tunggal, A. W. (2014). Konsep dan studi kasus internal auditing. Jakarta: Harvarindo.

Wiguna, P. W. (2012). Influence of leverage, firm size, profitability and liquidity against of voluntary disclosure. E-Jurnal Akuntansi Universitas Udayana, 2(1), 1-18. https://ojs.unud.ac.id/index.php/Akuntansi/article/view/4245/3266

Wijayanti, W. (2013). Analisis pengaruh corporate governance dan karakteristik perusahaan terhadap pengungkapan sukarela (voluntary disclosure) dalam laporan tahunan. Skripsi. Universitas Islam Negeri Syarif Hidayatullah Jakarta. http://repository.uinjkt.ac.id/dspace/bitstream/123456789/23850/1/semua\%20bab \%20skripsi.pdf 